\section{Pine Wood Chips as an Alternative to Perlite in Greenhouse Substrates: Nitrogen Requirements}

\author{
W. Garrett Owen ${ }^{1}$, Brian E. Jackson ${ }^{2,4}$, Brian E. Whipker ${ }^{3}$, \\ and William C. Fonteno ${ }^{3}$
}

ADDITIONAL INDEX WORDs. aggregate, fertilization, horticultural substrates, loblolly pine, plant nutrition, potting media

Summary. Processed pine wood (Pinus sp.) has been investigated as a component in greenhouse and nursery substrates for many years. Specifically, pine wood chips (PWC) have been uniquely engineered/processed into a nonfiberous blockular particle size, suitable for use as a substrate aggregate. In container substrates, nitrogen $(\mathrm{N})$ tie-up during crop production is of concern when substrates contain components with high carbon $(\mathrm{C}): \mathrm{N}$ ratios, like that of PWC that are made from fresh pine wood. The objective of this research was to compare the $\mathrm{N}$ requirements of plants grown in sphagnum peat-based substrates amended with perlite or PWC. Fertility concentrations of 100,200 , or $300 \mathrm{mg} \cdot \mathrm{L}^{-1} \mathrm{~N}$ were applied to 'Profusion Orange' zinnia (Zinnia $\times$ bybrida) and 'Moonsong Deep Orange' marigold (Tagetes erecta) grown in sphagnum peat-based substrates containing $10 \%, 20 \%$, or $30 \%$ (by volume) perlite or PWC. Zinnia plant substrate solution electrical conductivity (EC) was not influenced by percentage of perlite or PWC. Perlite-amended substrates fertilized with $200 \mathrm{mg} \cdot \mathrm{L}^{-1} \mathrm{~N}$ for growing zinnia, maintained a constant EC within optimal levels of 1.0 to $2.6 \mathrm{mS} \cdot \mathrm{cm}^{-1}$ from 14 to 42 days after planting (DAP), and then EC increased at 49 DAP. In substrates fertilized with 100 and $300 \mathrm{mg} \cdot \mathrm{L}^{-1} \mathrm{~N}$, EC levels steadily declined and then increased, respectively. Zinnia plants grown in PWC-amended substrates fertilized with $200 \mathrm{mg} \cdot \mathrm{L}^{-1} \mathrm{~N}$ maintained a constant EC within the optimal range from 14 to 49 DAP. Marigold substrate solution $\mathrm{EC}$ was only influenced by $\mathrm{N}$ concentration and followed a similar response to zinnia substrate solution EC. Zinnia and marigold substrate solution $\mathrm{pH}$ was influenced by $\mathrm{N}$ concentration and generally decreased with increasing $\mathbf{N}$ concentration. Plant growth and shoot dry weight were similar when fertilized with 100 and $200 \mathrm{mg} \cdot \mathrm{L}^{-1} \mathrm{~N}$. According to this study, plants grown in PWC-amended substrates fertilized with 100 to $200 \mathrm{mg} \cdot \mathrm{L}^{-1} \mathrm{~N}$ can maintain adequate substrate solution $\mathrm{pH}$ and $\mathrm{EC}$ levels and sustain plant growth with no additional $\mathrm{N}$ supplements. Pine wood chips are engineered and processed to specific sizes and shapes to be functional as aggregates in a container substrate. Not all wood components are designed or capable of improving/influencing the physical and chemical behavior of a substrate the same. On the basis of the variability of many wood components being developed and researched, it is suggested that any and all substrate wood components not be considered the same and be tested/trialed before large-scale use.

$\mathrm{T}$ The production of containergrown plants requires substrates that provide adequate chemical

Department of Horticultural Science, North Carolina State University, 130 Kilgore Hall, 2721 Founders Drive, Raleigh, NC 27695-7609

The cost of publishing this article was defrayed in part by payment of page charges.

Technical assistance of Ingram McCall is gratefully acknowledged.

Use of trade names does not imply endorsement of the products named or criticism of similar ones not mentioned.

${ }^{1}$ Former Graduate Research Assistant

${ }^{2}$ Associate Professor

${ }^{3}$ Professor

${ }^{4}$ Corresponding author. E-mail: brian_jackson@ncsu. edu. and physical properties. Traditional substrate mixes are formulated on a volume basis of peatmoss, vermiculite, perlite, and/or pine bark [PB (Nelson, 2012)]. In the United States, peatmoss is the primary base component and perlite is the primary aggregate used in greenhouse substrates; however, substrate manufacturers and growers are looking to decrease the use of traditional components that have high (or increasing) costs. Transportation and occasional peat/bark shortages in the past decade are the primary reasons for the increased costs (Jackson et al., 2008a), thus a higher demand for regional and lower cost alternatives.

Recent investigations of fresh wood as a substrate component for plant production have proven successful as an alternative for peatmoss (Boyer et al., 2008; Gerber et al., 1999; Jackson et al., 2008a; Wright et al., 2008). In contrast to peat-lite- (PL) and PB-based substrates, plant growth in substrates composed of large portions of wood have a tendency to become $\mathrm{N}$ deficient as a result of the high degree of $\mathrm{N}$ immobilization (Handreck, 1991, 1993; McKenzie, 1958). Nelson (2012) described the desirable properties of substrates for greenhouse crops, noted the importance of organic matter stability and the C:N ratio as it relates to $\mathrm{N}$ immobilization affecting plant growth during production. The high C:N ratio of wood substrates can result in the tieup of $\mathrm{N}$ from microbial immobilization, and wood substrate stability (decomposition) over time have been major concerns of researchers and growers (Boyer et al., 2012; Jackson et al., 2008b, 2009).

Wright and Browder (2005) demonstrated 'Inca Gold' marigold could be grown in substrates made from processed loblolly pine (Pinus taeda) chips (PC) at $100 \% \mathrm{PC}$, and $75 \% \mathrm{PC}$ : $25 \% \mathrm{~PB}$ (by volume) if additional nutrients were provided, with minimum growth differences when compared with plants grown in $100 \% \mathrm{~PB}$ substrates. Jackson et al. (2008a) reported 'Prestige' poinsettia (Euphorbia pulcherrima) growth response to be similar when grown in pine tree substrates (PTS) compared with PL or PB substrates at increasing fertility concentrations. They reported substrate solution

\begin{tabular}{llll}
\hline $\begin{array}{l}\text { Units } \\
\begin{array}{l}\text { To convert U.S. to SI, } \\
\text { multiply by }\end{array}\end{array}$ & U.S. unit & SI unit & $\begin{array}{l}\text { To convert SI to U.S., } \\
\text { multiply by }\end{array}$ \\
\hline 29.5735 & $\mathrm{fl} \mathrm{oz}$ & $\mathrm{mL}$ & 0.0338 \\
2.54 & inch $(\mathrm{es})$ & $\mathrm{cm}$ & 0.3937 \\
0.5933 & $\mathrm{lb} / \mathrm{yard} \mathrm{d}^{3}$ & $\mathrm{~kg} \cdot \mathrm{m}^{-3}$ & 1.6856 \\
1 & $\mathrm{mmho} / \mathrm{cm}$ & $\mathrm{mS} \cdot \mathrm{cm}^{-1}$ & 1 \\
28.3495 & $\mathrm{oz}$ & $\mathrm{g}$ & 0.0353 \\
1 & $\mathrm{ppm}$ & $\mathrm{mg} \cdot \mathrm{L}^{-1}$ & 1 \\
$\left({ }^{\circ} \mathrm{F}-32\right) \div 1.8$ & ${ }^{\circ} \mathrm{F}$ & ${ }^{\circ} \mathrm{C}$ & $\left({ }^{\circ} \mathrm{C} \times 1.8\right)+32$
\end{tabular}


EC values increased with increasing fertilizer concentrations and were higher in PL or PB than in PTS, thus demonstrating higher fertilizer concentrations were required to achieve comparable substrate solution EC levels for PTS compared with PL or PB (Jackson et al., 2008a, 2008b; Wright et al., 2008). In addition to $\mathrm{N}$ immobilization, nutrient leaching of wood-based substrates (dependent on processing of wood material and resultant particle size) has been proposed as a possible reason for lower EC and nutrient levels of PTS compared with PL or PB substrates during plant production (Jackson et al., 2009a; Wright and Browder, 2005; Wright et al., 2008).

Jackson and Wright (2009) found shoot dry weight of marigold plants grown in $100 \%$ PTS to increase as peat amendment increased when fertilized with 50,100 , and $200 \mathrm{mg} \cdot \mathrm{L}^{-1}$ $\mathrm{N}$. When plants were fertilized with $300 \mathrm{mg} \cdot \mathrm{L}^{-1} \mathrm{~N}$, shoot dry weight of plants grown in at least 40\% PTS (by volume) with the remainder being peat, did not increase with increasing peat amendment. Without additional peat amendment, plants and substrate microbes were supplied with sufficient $\mathrm{N}$, thus minimizing effects of microbial $\mathrm{N}$ immobilization. Fain et al. (2008) showed similar results with petunia (Petunia $\times$ bybrid) grown in various percentages of a pine wood substrates and peatmoss. Petunia growth was larger in substrate treatments containing peatmoss compared with $100 \%$ pine wood. Petunia grown in substrates containing wood increased in shoot mass when additional fertilizer was supplied. Decreased plant growth in wood-based substrates is generally only a concern when fertility levels (primarily $\mathrm{N}$ ) are below optimal recommended levels for growth and development (Hicklenton, 1983). Wright et al. (2008) also found plant growth of 'Baton Rouge' chrysanthemum (Chrysanthemum $\times$ grandiflora) grown in $100 \%$ PTS, required an additional $100 \mathrm{mg} \cdot \mathrm{L}^{-1}$ of $\mathrm{N}$ fertilizer to obtain comparable growth to a PL substrate composed of $45 \%$ peat, $15 \%$ perlite, $15 \%$ vermiculite, and $25 \%$ bark (by volume).

No information is available regarding fertility requirements for peat-based substrates amended with aggregates of PWCs, which is a different material (size, structure, particle shape, etc.) than previous wood components tested. Therefore, the objective of this study was to determine $\mathrm{N}$ recommendations for optimal plant growth in peat-based substrates amended with perlite or PWC aggregates at various ratios.

\section{Materials and methods}

On 19 Dec. 2011, 8-year-old loblolly pine trees were harvested (Chatham County, NC) at ground level, de-limbed, and subsequently stored under shelter for protection from the weather. On 3 Jan. 2012, these logs were chipped (with their bark intact) with an 18-horsepower chipper (model 356447; DR Power Equipment, Vergennes, VT) resulting in large wood chips $[1 \times 0.2 \times 1.0 \mathrm{~cm}$ (length $\times$ width $\times$ height); $\mathrm{n}=20$ (Fig. 1A)]. Wood chips were then spread out ( 1 inch deep) on a concrete pad under shelter, turned periodically and allowed to air-dry for $2 \mathrm{~d}$ to reduce moisture content, which has been shown in unpublished studies to aid in the efficient processing of wood through hammer mills. In this experiment, the moisture content of the fresh wood chips was $43 \%$ after chipping and 35\% after air-drying for $2 \mathrm{~d}$, resulting in a moisture loss of $8 \%$. Wood chips were then hammer milled through a $1 / 4$-inch screen (Meadows Mills, North Wilkesboro, NC) resulting in smaller PWC $[0.11 \times 0.4 \times 0.2 \mathrm{~cm}$ (length $\times$ width $\times$ height); $n=20$ (Fig. 1B)]. On 11 Jan., sphagnum peat (ProMoss Sphagnum Peat, Quakertown, PA) was taken from a compressed bale, loosened/fluffed, and wetted (by hand) to a moisture content of $50 \%$ (by weight) before being amended with
$10 \%, 20 \%$, or $30 \%$ (by volume) perlite (Carolina Perlite Co., Gold Hill, NC) or PWC to produce a total of six substrate treatments. After formulation of the substrates, initial substrate $\mathrm{pH}$ was determined by the $2: 1$ extract method [2 substrate: 1 deionized water (Argo and Fisher, 2002)] using a $\mathrm{pH}$ instrument (HI 9813-6; Hanna Instruments, Woonsocket, RI). After determining initial substrate $\mathrm{pH}$, dolomitic limestone was incorporated at a rate of $12 \mathrm{lb} /$ yard $^{3}$ and wetting agent (2000G; Aquatrols, Paulsboro, NJ) at a rate of $0.5 \mathrm{lb} /$ yard $^{3}$. Substrates were incubated for $4 \mathrm{~d}$ in sealed plastic bags to allow for lime/ $\mathrm{pH}$ equilibration before potting. Substrates did not contain a preplant fertilizer.

EXPERIMENT 1. On 27 Jan. 2012, 6-inch-diameter plastic containers (ITML Horticultural Products, Middlefield, $\mathrm{OH}$ ) were filled with each of the six previously described substrates. 'Profusion Orange' zinnia seeds were direct, double sown at a depth of $1 \mathrm{~cm}$ in the substrate-filled containers. The seedlings were grown in a polyethylene greenhouse in Raleigh, NC, and grown with $23 / 17^{\circ} \mathrm{C}$ (day/night) air temperature settings (temperatures not monitored during growth trial). All plants were watered as needed (when the surface began to dry) depending upon weather conditions. Equal volumes of irrigation solutions $(\approx 150 \mathrm{~mL})$ were applied to all substrates at each irrigation as a result of the water-holding capacities of all substrates were within $7 \%$ of each other (data not shown), according to substrate physical property analysis performed on all substrate blends before potting, using

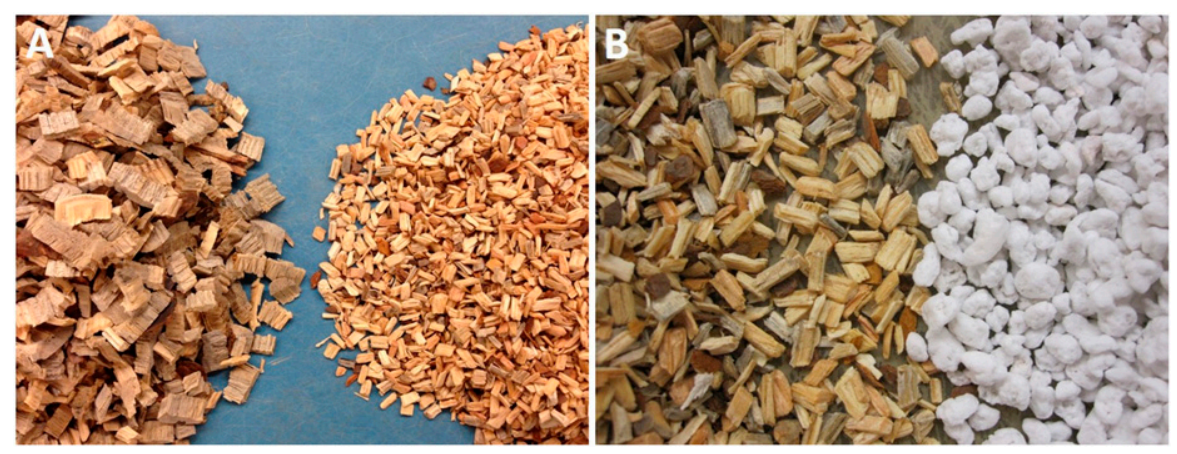

Fig. 1. (A) Harvested loblolly pine logs were chipped in a wood chipper resulting in large wood chips $[1.0 \times 0.2 \times 1.0 \mathrm{~cm}$ (length $\times$ width $\times$ height) $]$ before being milled through a $1 / 4$-inch $(6.35 \mathrm{~mm})$ hammer mill screen resulting in (B) smaller pine wood chip aggregates that are square/blockular in nature and contain little dust or fibers and are similar in size to horticultural grade perlite; $1 \mathrm{~cm}=0.3937$ inch. 
the North Carolina State University porometer method. On 2 Feb., one of the double-sown zinnia seedlings was pinched at the substrate level to remove it and allow a single seedling to remain in each pot.

Plants were treated with constant liquid fertilizer at each watering, beginning with the first watering after thinning, with 100,200 , or $300 \mathrm{mg} \cdot \mathrm{L}^{-1} \mathrm{~N}$, provided by equal $\mathrm{N}$ combinations of $20 \mathrm{~N}-4.4 \mathrm{P}-16.6 \mathrm{~K}$ water-soluble fertilizer (Peters Professional Peat-Lite Special; Scotts, Marysville, $\mathrm{OH}$ ) containing $8.1 \%$ ammonical $\left(\mathrm{NH}_{4}\right) \mathrm{N}$ and $11.9 \%$ nitrate $\left(\mathrm{NO}_{3}\right) \mathrm{N}$ and $13 \mathrm{~N}-0.9 \mathrm{P}-10.8 \mathrm{~K}$ water-soluble fertilizer (Cal-Mag; SQM North America, Atlanta, GA) containing $0.3 \% \mathrm{NH}_{4}-\mathrm{N}$ and $12.7 \% \mathrm{NO}_{3}-\mathrm{N}$. The fertility treatments consisted of 25 , 50 , or $75 \mathrm{~g}$ of $20 \mathrm{~N}-4.4 \mathrm{P}-16.6 \mathrm{~K}$ and 39,77 , or $115 \mathrm{~g}$ of $13 \mathrm{~N}-0.9 \mathrm{P}-10.8 \mathrm{~K}$ fertilizers to produce 100,200 , or $300 \mathrm{mg} \cdot \mathrm{L}^{-1} \mathrm{~N}$, respectively. The watersoluble fertilizers were weighed and dissolved together in separate $100-\mathrm{L}$ fertilizer tanks to achieve 100, 200, or $300 \mathrm{mg} \cdot \mathrm{L}^{-1} \mathrm{~N}$. Fertilizer solutions were supplied to plants by irrigation lines constructed with drip rings. Five containers of each substrate were randomized on irrigation lines at bench level, and drip rings were placed on top of the substrate for each container, corresponding to the fertility treatment. Substrate solution was extracted $\mathrm{l} \mathrm{h}$ after irrigation and collected weekly for 6 weeks using the pour-through method (Wright, 1986) and was analyzed for $\mathrm{EC}$ and $\mathrm{pH}$. The experiment was a factorial design arranged in a completely randomized manner with five single-plant replications $\times$ six substrates $\times$ three $\mathrm{N}$ concentrations. On 23 Mar., a final growth index [GI $=$ (height + widest width + perpendicular width) $\div 3$ ] of each plant was recorded at the first sign of anthesis, and total plant height was measured (from the substrate surface to the top of the bloom). Stems were severed at the substrate surface, dried at $70{ }^{\circ} \mathrm{C}$ for 1 week, and weighed.

ExPERIMENT 2. Except where indicated, procedures were the same as described in Expt. 1. On 12 Mar. 2012, 'Moonsong Deep Orange' marigold seeds were sown into 288 plug trays containing Fafard Germination mix (Conrad Fafard, Anderson, SC) in a glasshouse in Raleigh, NC. For Expt. 2, the same six substrate ratios used in Expt. 1 were formulated on 11 Jan. and stored in sealed plastic bags without dolomitic limestone incorporation. Sealed plastic bags were stored under shelter and protected from the weather. On 30 Mar., dolomitic limestone was incorporated at $10 \mathrm{lb} / \mathrm{yard}^{3}$. A lower amount of lime was incorporated in Expt. 2 to achieve $\mathrm{pH}$ of 5.8 , determined by initial substrate $\mathrm{pH}$. On 4 Apr., 4-week-old germinated seedlings were transplanted in 6-inch plastic containers filled with each substrate. Substrate solution was collected weekly for 5 weeks and analyzed for EC and pH. On 11 May, final GI of each plant was measured and recorded. Stems were severed at the substrate surface, dried at $70{ }^{\circ} \mathrm{C}$ for $\mathrm{l}$ week, and weighed. EC data were subjected to analysis of variance by the general linear model procedures and regression analysis (version 9.4; SAS Institute, Cary, NC). Plant height, diameter, GI, dry weight, and $\mathrm{pH}$ means were separated by Duncan's multiple range test $(P \leq 0.05)$.

\section{Results and discussion}

Substrate SOLUTION EC. Zinnia substrate solution EC was not influenced by percentage of aggregate $(10 \%, 20 \%$, or $30 \%)$; therefore, substrate solution EC data were pooled and analyzed by aggregate type (perlite or PWC) and $\mathrm{N}$ concentration. There was a significant linear and quadratic relationship between substrate solution EC and $\mathrm{N}$ rate at 14 , $21,28,35,42$, and 49 DAP for perlite- or PWC-amended substrates (Fig. 2A and B). EC levels of substrates amended with perlite or PWC followed a similar trend from 14 to 49 DAP. Substrate solution EC was similar between 14 and 42 DAP but different at 49 DAP for each $\mathrm{N}$ concentration.

Substrate solution EC of both substrates fertilized with $100 \mathrm{mg} \cdot \mathrm{L}^{-1}$ $\mathrm{N}$ resulted in a steady decline from 1.71 to $0.72 \mathrm{mS} \cdot \mathrm{cm}^{-1}$ for perliteamended substrates and 1.02 to $0.66 \mathrm{mS} \cdot \mathrm{cm}^{-1}$ for PWC-amended substrates from 14 to 49 DAP (Fig. 2A and B). Whipker et al. (2001) indicated that the recommended pourthrough extract EC range for zinnia was 1.0 to $2.6 \mathrm{mS} \cdot \mathrm{cm}^{-1}$. Therefore, plants fertilized with $100 \mathrm{mg} \cdot \mathrm{L}^{-1} \mathrm{~N}$ achieved the recommended EC levels between 14 and 28 DAP for both substrates and continuously declined beyond 28 DAP.
Substrate solution EC of plants supplied with $200 \mathrm{mg} \cdot \mathrm{L}^{-1} \mathrm{~N}$ held fairly constant (Fig. 2A and B). In perlite-amended substrates, solution ECs were consistent and within recommended EC levels from 14 to 42 DAP, but increased to $1.42 \mathrm{mS} \cdot \mathrm{cm}^{-1}$ at $42 \mathrm{DAP}$, which was above the recommended range for zinnia. Unlike substrates amended with perlite, substrate solution EC of PWCamended substrates fertilized with $200 \mathrm{mg} \cdot \mathrm{L}^{-1} \mathrm{~N}$ remained relatively consistent between recommended EC levels from 14 to 49 DAP. Kang and van Iersel (2009) found a similar trend when 'Gnome White' petunia were irrigated with a fertilizer solution EC of $1.5 \mathrm{mS} \cdot \mathrm{cm}^{-1}$.

Substrate solution EC of zinnia plants grown in substrates amended with perlite or PWC and fertilized with $300 \mathrm{mg} \cdot \mathrm{L}^{-1} \mathrm{~N}$ resulted in a steady increase from 2.10 to $3.93 \mathrm{mS} \cdot \mathrm{cm}^{-1}$ and 2.00 to $3.95 \mathrm{mS} \cdot \mathrm{cm}^{-1}$ for perliteand PWC-amended substrates, respectively, from 14 to 49 DAP (Fig. 2A and B). Kang and van Iersel (2009) also reported constant liquid fertilizer concentrations above $2.5 \mathrm{mS} \cdot \mathrm{cm}^{-1}$ supplied to petunias to increase substrate solution EC, as a result of additional fertilizer applied to the substrate than taken up by the plant. Plants grown in both substrates amended with perlite or PWC and fertilized with $300 \mathrm{mg} \cdot \mathrm{L}^{-1} \mathrm{~N}$ maintained recommended EC levels from 14 to 21 DAP. Substrate solution EC of both substrates continuously increased above recommended EC levels for zinnia beyond $28 \mathrm{DAP}$. An increase in substrate solution EC with increasing fertilizer concentration throughout the experiment is consistent with previous findings (James and van Iersel, 2001; Kang and van Iersel, 2001, 2009; Nemali and van Iersel, 2004).

Data pooled by $\mathrm{N}$ concentration and sampling time for marigold plants grown in perlite- and PWC-amended substrates resulted in a significant linear and quadratic relationship between $11,18,25,32$, and 39 DAT (Fig. 3). From 11 to 39 DAT, substrate solution ECs of marigold plants were similar and followed a similar trend of zinnia plants. Marigold plants grown in perlite- or PWC-amended substrates and fertilized with $100 \mathrm{mg} \cdot \mathrm{L}^{-1} \mathrm{~N}$ resulted in a steady decline from 0.99 to $0.49 \mathrm{mS} \cdot \mathrm{cm}^{-1}$. Substrate solution EC of plants fertilized with $200 \mathrm{mg} \cdot \mathrm{L}^{-1} \mathrm{~N}$, 

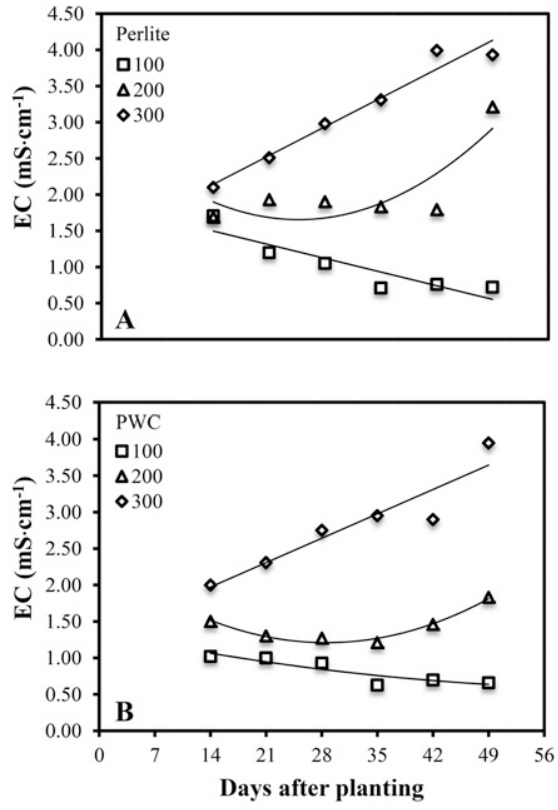

Fig. 2. Electrical conductivity (EC) levels of 'Profusion Orange' zinnia grown in perlite-amended substrates (A) fertilized at $100 \mathrm{mg} \cdot \mathrm{L}^{-1}$ nitrogen $\left[\mathrm{N}\left(y=0.11 x-1.33\right.\right.$; adjusted $R^{2}=$ $\left.\left.0.5723 \mathrm{~L}^{* * *}, \mathrm{Q}^{\mathrm{NS}}\right)\right], 200 \mathrm{mg} \cdot \mathrm{L}^{-1}[\mathrm{~N}$ $\left(y=0.10 x^{2}-0.53 x+2.32\right.$; adjusted $\left.\left.R^{2}=0.3646 \mathrm{~L}^{* * *}, \mathrm{Q}^{* *}\right)\right]$, or $300 \mathrm{mg} \cdot \mathrm{L}^{-1}[\mathrm{~N}(y=0.40 x+1.74$; adjusted $\left.\left.R^{2}=0.5987 \mathrm{~L}^{* * *}, \mathrm{Q}^{\mathrm{NS}}\right)\right]$. EC levels of 'Profusion Orange' zinnia grown in pine wood chip (PWC)amended substrates (B) fertilized at $100 \mathrm{mg} \cdot \mathrm{L}^{-1}[\mathrm{~N}(y=0.08 x-1.12$; adjusted $\left.\left.R^{2}=0.4176 ; \mathrm{L}^{* * *}, \mathrm{Q}^{\mathrm{NS}}\right)\right]$ $200 \mathrm{mg} \cdot \mathrm{L}^{-1}\left[\mathrm{~N}\left(y=0.07 x^{2}-0.44 x+\right.\right.$ 1.89; adjusted $R^{2}=0.2328 \mathrm{~L}^{\mathrm{NS}}$, $\left.\left.\mathrm{Q}^{* * *}\right)\right]$, or $300 \mathrm{mg} \cdot \mathrm{L}^{-1}[\mathrm{~N}(y=0.33 x+$ 1.64; adjusted $R^{2}=0.5049 \mathrm{~L}^{* * *}$, $\left.\mathrm{Q}^{\mathrm{NS}}\right)$ ]. Data were pooled over aggregate type and $\mathrm{N}$ concentration $(\mathbf{n}=9)$. Nonsignificant (NS) or significant; linear (L) or quadratic (Q) response for concentration at *, **, or ${ }^{* * *}$, where $P \leq 0.05,0.01$, or 0.001 , respectively; $1 \mathrm{mg} \cdot \mathrm{L}^{-1}=1$ ppm, $1 \mathrm{mS} \cdot \mathrm{cm}^{-1}=1 \mathrm{mmho} / \mathrm{cm}$.

held fairly constant over the duration of 5 weeks, while plants fertilized with an additional $100 \mathrm{mg} \cdot \mathrm{L}^{-1} \mathrm{~N}$ resulted in an increase from 2.77 to $4.16 \mathrm{mS} \cdot \mathrm{cm}^{-1}$ from 11 to 39 DAT. According to Whipker et al. (2001), substrate solution EC of marigold plants were in recommended pour-through extract EC range of 1.0 to $2.6 \mathrm{mS} \cdot \mathrm{cm}^{-1}$ when fertilized with $200 \mathrm{mg} \cdot \mathrm{L}^{-1} \mathrm{~N}$. Substrate solution EC levels of perlite- or PWC-amended substrates were not within recommended EC range for marigold plants when fertilized with 100 or $300 \mathrm{mg} \cdot \mathrm{L}^{-1} \mathrm{~N}$.
Substrate SOlution pH. Zinnia substrate solution $\mathrm{pH}$ was the same for aggregate type and percent of aggregate; therefore, substrate solution $\mathrm{pH}$ data were pooled and analyzed by $\mathrm{N}$ concentration. Results indicate as $\mathrm{N}$ concentration increased, substrate solution $\mathrm{pH}$ decreased. The mean substrate solution $\mathrm{pH}$ of zinnia plants grown in both perlite- and PWCamended substrates fertilized at 100 , 200 , and $300 \mathrm{mg} \cdot \mathrm{L}^{-1} \mathrm{~N}$ were (mean \pm SE) $6.2 \pm 0.37,5.7 \pm 0.30$, and $5.5 \pm$ 0.32 , respectively (data not shown). Overall, though, substrate solution $\mathrm{pH}$ for zinnia plants fertilized with $100 \mathrm{mg} \cdot \mathrm{L}^{-1} \mathrm{~N}$ was within the acceptable range of $\mathrm{pH} 6.2$ to 6.5 for zinnia growth (Nau, 2011). For marigold, the substrate solution $\mathrm{pH}$ decreased with decreasing aggregate amendment. This trend is supported by Jackson et al. (2009b) who observed $\mathrm{pH}$ to be highest in $100 \%$ PTS substrate compared with a PL substrate, and $\mathrm{pH}$ generally decreased as the proportion of peat increased. Overall, substrates amended with 30\% perlite or PWC and fertilized at all fertility concentrations had the highest substrate solution $\mathrm{pH}$, which decreases with increasing peat. Similarly, Wright et al. (2008) found that substrate $\mathrm{pH}$ followed the normal response of decreasing with increasing fertilizer rate for PL and PTS. Overall, substrates amended with $20 \%$ perlite or PWC and fertilized with $100 \mathrm{mg} \cdot \mathrm{L}^{-1} \mathrm{~N}$ were in acceptable $\mathrm{pH}$ range for marigold growth ( $\mathrm{pH} 6.2$ to 6.5). However, plants grown in substrates amended with $10 \%$ and $30 \%$ perlite or PWC and fertilized with $100 \mathrm{mg} \cdot \mathrm{L}^{-1}$ $\mathrm{N}$, achieved a $\mathrm{pH} 6.1$ and 6.7 (higher $\mathrm{pH}$ values than is recommended for marigold growth), respectively. Also, in marigold plants grown in $10 \%, 20 \%$, or $30 \%$ perlite- or PWC-amended substrates and fertilized with 200 and $300 \mathrm{mg} \cdot \mathrm{L}^{-1} \mathrm{~N}$, substrate solution $\mathrm{pH}$ values were high and not within the recommended marigold substrate $\mathrm{pH}$ range.

Zinnia plants fertilized at all $\mathrm{N}$ treatments did not exhibit any visual nutrient deficiencies or toxicities. Marigold plants grown only in the substrate amended with $10 \%$ perlite and fertilized with 100 and $300 \mathrm{mg} \cdot \mathrm{L}^{-1} \mathrm{~N}$ exhibited lower leaf purpling at 15 DAT. The discoloration of marigold leaves is likely caused by the high substrate $\mathrm{pH}$ and its possible effect on phosphorus availability or due to excessive irrigation.

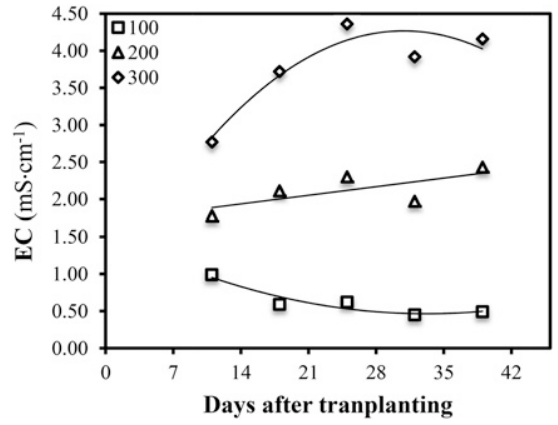

Fig. 3. Pooled data of electrical conductivity (EC) levels for

'Moonsong Deep Orange' marigold grown in perlite- amended and pine wood chip-amended substrates fertilized at $100 \mathrm{mg} \cdot \mathrm{L}^{-1}$ nitrogen [ $\mathrm{N}$ $\left(y=0.05 x^{2}-0.40 x-1.29 ;\right.$ adjusted $\left.\left.R^{2}=0.6125 \mathrm{~L}^{* * *}, \mathrm{Q}^{* * *}\right)\right]$, $200 \mathrm{mg} \cdot \mathrm{L}^{-1} \mathrm{~N}(y=0.12 x+1.76$; adjusted $\left.R^{2}=0.1434 \mathrm{~L}^{* * *}, \mathrm{Q}^{\mathrm{NS}}\right)$, or $300 \mathrm{mg} \cdot \mathrm{L}^{-1} \mathrm{~N}\left(y=0.18 x^{2}-1.38 x+\right.$ 1.63; adjusted $R^{2}=0.3624 \mathrm{~L}^{* * *}$, $\left.Q^{* * *}\right)$. Nonsignificant (NS) or significant; linear $(\mathrm{L})$ or quadratic $(\mathrm{Q})$ response for concentration at *, **, or ***, where $P \leq 0.05,0.01$, or 0.001 , respectively; $1 \mathrm{mg} \cdot \mathrm{L}^{-1}=1$ $\mathrm{ppm}, 1 \mathrm{mS} \cdot \mathrm{cm}^{-1}=1 \mathrm{mmho} / \mathrm{cm}$.

However at 39 DAT, plants did not exhibit any nutritional deficiencies or toxicities.

Difference of substrate $\mathrm{pH}$ for both species may be caused by the rates of 200 -mesh ( $60 \%$ screening) dolomitic lime amended to the substrates. Materials used to formulate substrates to grow zinnia had an initial $\mathrm{pH}$ of about 4.2 before liming. Dolomitic lime was incorporated at $12 \mathrm{lb} /$ $\operatorname{yard}^{3}, 3 \mathrm{~d}$ before use to allow for lime equilibration, resulting in $\mathrm{pH} \approx 6.2$; which was within the recommended $\mathrm{pH}$ range for zinnia plants. Substrate formulated for marigold had an initial $\mathrm{pH} \approx 4.1$ before liming. Based on previous studies, a lower rate of dolomitic lime $10 \mathrm{lb} /$ yard $^{3}$ was incorporated in the formulated substrates to achieve a target substrate $\mathrm{pH} \approx 5.8$.

The reactive fraction or the fraction of dolomitic limestone that initially reacts to increase $\mathrm{pH}$ to a stable level, 5 to 10 DAP was achieved for zinnia and marigold plants. However, the residual or the unreacted limestone affects the substrate's long-term buffering capacity or the ability to minimize fluctuations in $\mathrm{pH}$ (Argo and Fisher, 2002) may have been reduced when dolomitic lime of $10 \mathrm{lb} /$ yard $^{3}$ was incorporated in substrates to grow 
marigold plants. Argo and Fisher (2002) demonstrated that the amount of residual lime contained in a substrate can influence the overall $\mathrm{pH}$ reaction in the substrate and override the effects of fertilizers. In this study, the normal response of substrate $\mathrm{pH}$ decreasing with increasing $\mathrm{N}$ concentration for substrates amended with perlite or PWC was observed. It has been reported by Wright et al. (2008) that $100 \%$ PTS normally has a proper $\mathrm{pH}$ range for plant growth with no addition of dolomitic limestone incorporated into PTS compared with PB and PL. Therefore, preplant/pre-pot initial testing and lime reactivity is recommended for any substrate with wood components (of any percent) in them.

Frequent monitoring of substrate solution EC and $\mathrm{pH}$ is recommended (Cavins et al., 2000) as well as matching a suitable fertility program to the crop. Despite similar EC and $\mathrm{pH}$ data in these trials, there is other evidence and discussion in recent literature to suggest that different wood components can alter substrate chemical properties in different ways. Most notably, increased ratios of some wood components have been shown in other works to increase substrate $\mathrm{pH}$ and decrease EC during crop production (Jackson and Wright, 2009).

Plant height. Zinnia height was not influenced by aggregate type, percentage, or $\mathrm{N}$ concentration with a mean overall height of $14.3 \mathrm{~cm}$ for all treatments. Marigold height was not influenced by aggregate type or the percentage of perlite- or PWCamended substrates; therefore, plant height data were pooled and analyzed by $\mathrm{N}$ concentration with significant differences between $\mathrm{N}$ concentrations. In perlite- and PWC-amended substrates, plant height was greatest when fertilized with $100 \mathrm{mg} \cdot \mathrm{L}^{-1} \mathrm{~N}$ and was $4 \%$ and $7 \%$ shorter when fertilized with 200 and $300 \mathrm{mg} \cdot \mathrm{L}^{-1} \mathrm{~N}$, respectively, as represented visually in Fig. 4. Shorter plant height could be contributed to high substrate solution EC, not recommended for marigold culture when fertilized with $300 \mathrm{mg} \cdot \mathrm{L}^{-1} \mathrm{~N}$. Also, the substrate $\mathrm{pH}$ was not within the recommended $\mathrm{pH}$ range when plants were fertilized with 200 and $300 \mathrm{mg} \cdot \mathrm{L}^{-1} \mathrm{~N}$, which may contribute to shorter plant height.

Diameter. Zinnia and marigold plant diameter was not influenced by aggregate or percentage of perlite- or PWC-amended substrates; therefore, plant diameter data were pooled and analyzed by $\mathrm{N}$ concentration. For zinnia, plant diameter was smaller as $\mathrm{N}$ concentration increased while marigold plant diameter increased as $\mathrm{N}$ concentration increased (Table $\mathrm{l}$ ). Zinnia plant diameter was $3 \%$ and $8 \%$ smaller when fertilized with 200 and $300 \mathrm{mg} \cdot \mathrm{L}^{-1} \mathrm{~N}$, respectively, compared with plants fertilized with $100 \mathrm{mg} \cdot \mathrm{L}^{-1} \mathrm{~N}$. In both perlite- and PWC-amended substrates, marigold plant diameter increased by $9 \%$ and $8 \%$ when fertilized with 200 and $300 \mathrm{mg} \cdot \mathrm{L}^{-1} \mathrm{~N}$, respectively, compared with plants fertilized with $100 \mathrm{mg} \cdot \mathrm{L}^{-1} \mathrm{~N}$. Visually, zinnia and marigold plant diameters were similar.

GrowTH INDEX. Zinnia and marigold GI was not influenced by aggregate type or the percent of aggregates; therefore, plant growth data were pooled and analyzed by $\mathrm{N}$ concentration. In general for zinnia growth, as $\mathrm{N}$ concentration increased, overall plant size was less. Zinnia plants fertilized with $100 \mathrm{mg} \cdot \mathrm{L}^{-1} \mathrm{~N}$ were the largest with a mean GI of $18.36 \mathrm{~cm}$, compared with plants fertilized with 200 and $300 \mathrm{mg} \cdot \mathrm{L}^{-1} \mathrm{~N}$ (Table $\mathrm{l}$ ). Growth indices of zinnia plants fertilized with $200 \mathrm{mg} \cdot \mathrm{L}^{-1} \mathrm{~N}$ were similar to GI of plants at 100 or $300 \mathrm{mg} \cdot \mathrm{L}^{-1} \mathrm{~N}$. Overall, marigold plants fertilized with $200 \mathrm{mg} \cdot \mathrm{L}^{-1} \mathrm{~N}$ were largest with a mean GI of $23.43 \mathrm{~cm}$, compared with plants fertilized with 100 or $300 \mathrm{mg} \cdot \mathrm{L}^{-1} \mathrm{~N}$ (Table 1). However, GIs of marigold plants fertilized with $300 \mathrm{mg} \cdot \mathrm{L}^{-1} \mathrm{~N}$ were similar to plants at 100 and $200 \mathrm{mg} \cdot \mathrm{L}^{-1} \mathrm{~N}$. Visually there were no differences in overall zinnia and marigold plant size. Larger zinnia and marigold plant size can likely be attributed to similar substrate physical properties at each percent/rate of each aggregate type (data not shown) and acceptable substrate solution $\mathrm{pH}$. Lower substrate solution EC and smaller overall plant size indicate plants were receiving insufficient amounts of nutrition when fertilized with $100 \mathrm{mg} \cdot \mathrm{L}^{-1} \mathrm{~N}$. As a result, high substrate solution EC from excessive fertility provided by $300 \mathrm{mg} \cdot \mathrm{L}^{-1} \mathrm{~N}$ led to less plant growth for both species.

SHOot DRY WEIGHT. Zinnia and marigold shoot dry weight was not influenced by aggregate type or percent of aggregate; therefore, shoot dry

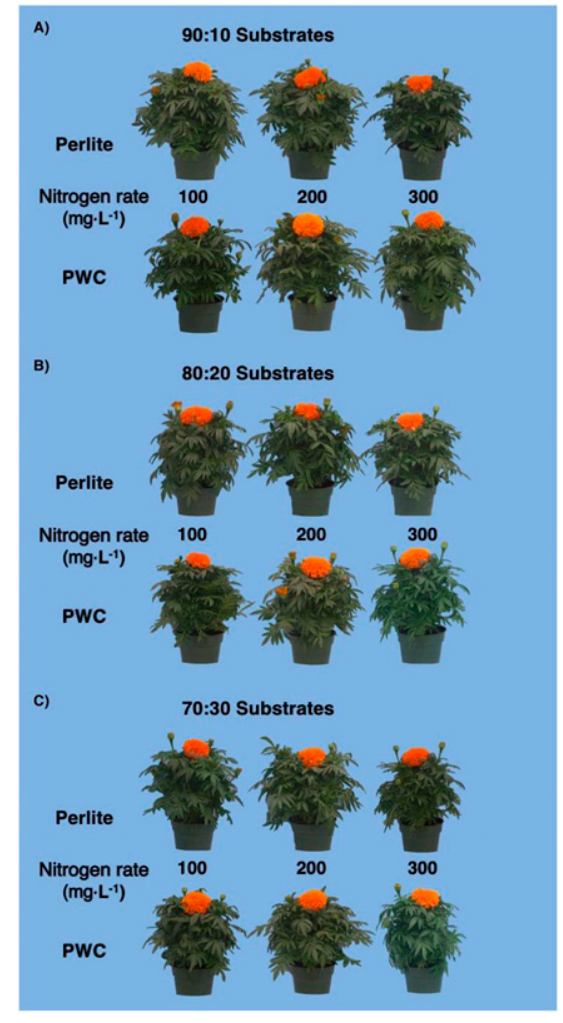

Fig. 4. Visual illustration of 5-weekold 'Moonsong Deep Orange' marigold plants grown in peat substrates amended with (A) $10 \%$, (B) $20 \%$, or (C) $30 \%$ perlite or pine wood chip (PWC) aggregates (by volume) and fertilized at 100,200 , or $300 \mathrm{mg} \cdot \mathrm{L}^{-1} \mathrm{~N}$; $1 \mathrm{mg} \cdot \mathrm{L}^{-1}=1 \mathrm{ppm}$.

weight data were pooled and analyzed by $\mathrm{N}$ concentration. Zinnia shoot dry weight of plants increased by $7 \%$ when fertilized with $200 \mathrm{mg} \cdot \mathrm{L}^{-1} \mathrm{~N}$ and decreased by $5 \%$ when fertilized with $300 \mathrm{mg} \cdot \mathrm{L}^{-1} \mathrm{~N}$, compared with plants fertilized with $100 \mathrm{mg} \cdot \mathrm{L}^{-1} \mathrm{~N}$ (Table 1 ). There was $11 \%$ reduction in shoot dry weight between 200 and $300 \mathrm{mg} \cdot \mathrm{L}^{-1} \mathrm{~N}$; however, zinnia shoot dry weight was similar at all $\mathrm{N}$ concentration. Marigold shoot dry weight increased by $19 \%$ when plants were fertilized with 200 $\mathrm{mg} \cdot \mathrm{L}^{-1} \mathrm{~N}$ and by $9 \%$ when fertilized with $300 \mathrm{mg} \cdot \mathrm{L}^{-1} \mathrm{~N}$, compared with plants fertilized with $100 \mathrm{mg} \cdot \mathrm{L}^{-1} \mathrm{~N}$ concentration. Shoot dry weight that was $10 \%$ smaller occurred between plants when fertilized with 200 and $300 \mathrm{mg} \cdot \mathrm{L}^{-1} \mathrm{~N}$, as a result of higher than recommended substrate solution EC levels. Marigold shoot dry weight was different in all $\mathrm{N}$ concentrations with the highest shoot dry weight occurring when marigold were fertilized with $200 \mathrm{mg} \cdot \mathrm{L}^{-1} \mathrm{~N}$. Kang and van Iresel (2009) reported a similar 
Table 1. Effect of nitrogen (N) concentration on zinnia and marigold height, diameter, growth index (GI), and shoot dry weight, grown in substrates amended with $10 \%, 20 \%$, and $30 \%$ (by volume) perlite or pine wood chips fertilized with 100 , 200 , or $300 \mathrm{mg} \cdot \mathrm{L}^{-1} \mathrm{~N}$.

\begin{tabular}{|c|c|c|c|c|c|c|c|c|}
\hline \multirow[b]{2}{*}{$\mathrm{N} \operatorname{concn}\left(\mathrm{mg} \cdot \mathrm{L}^{-1}\right)^{\mathrm{z}}$} & \multicolumn{2}{|c|}{ Plant ht $(\mathrm{cm})^{\mathrm{z}}$} & \multicolumn{2}{|c|}{ Plant diam $(\mathrm{cm})$} & \multicolumn{2}{|c|}{$\mathrm{GI}(\mathrm{cm})^{\mathrm{y}}$} & \multicolumn{2}{|c|}{ Shoot dry wt $(g)^{z}$} \\
\hline & Zinnia & Marigold & Zinnia & Marigold & Zinnia & Marigold & Zinnia & Marigold \\
\hline 100 & $14.5 \mathrm{a}^{\mathrm{x}}$ & $24.2 \mathrm{a}$ & $20.3 \mathrm{a}$ & $21.4 \mathrm{~b}$ & $18.4 \mathrm{a}$ & $22.4 \mathrm{~b}$ & $5.7 \mathrm{ab}$ & $12.3 \mathrm{c}$ \\
\hline 200 & $14.0 \mathrm{a}$ & $23.3 \mathrm{~b}$ & $19.7 \mathrm{ab}$ & $23.5 \mathrm{a}$ & $17.8 \mathrm{ab}$ & $23.4 \mathrm{a}$ & $6.1 \mathrm{a}$ & $14.6 \mathrm{a}$ \\
\hline 300 & $14.3 \mathrm{a}$ & $22.4 \mathrm{c}$ & $18.6 \mathrm{~b}$ & $23.2 \mathrm{a}$ & $17.1 \mathrm{~b}$ & $22.9 \mathrm{ab}$ & $5.4 \mathrm{~b}$ & $13.4 \mathrm{~b}$ \\
\hline
\end{tabular}

${ }^{\mathrm{z}} \mathrm{l} \mathrm{mg} \cdot \mathrm{L}^{-1}=1 \mathrm{ppm}, \mathrm{l} \mathrm{cm}=0.3937$ inch, $1 \mathrm{~g}=0.0353 \mathrm{oz}$

${ }^{y} \mathrm{GI}=$ (height + widest width + perpendicular width $) \div 3$

'Mean separated within column by Duncan's multiple range test $(P \leq 0.05)$.

response when petunias were fertilized with $200 \mathrm{mg} \cdot \mathrm{L}^{-1} \mathrm{~N}$.

Similar plant growth from zinnia and marigold grown in substrates with $30 \%$ wood, even at lower $\mathrm{N}$ concentrations $\left(100 \mathrm{mg} \cdot \mathrm{L}^{-1}\right)$ provides supportive data toward better understanding the $\mathrm{N} /$ fertility dynamics of using raw/fresh/unaged organic components like wood in horticultural substrates. Nitrogen demands and immobilization rates are among the top concerns of academic and industry researchers, soil/substrate manufacturers, and growers relative to the perception that all fresh wood substrates or substrate components will tie-up (immobilize) much of the $\mathrm{N}$ in the system leading to stunted or yellow plants. It is not the opinion of these authors that this work proves that $\mathrm{N}$-immobilization is absent, but instead the message here is that when using these particularly engineered blockular wood particles, their influence on the chemical properties of a peat-based substrate are negligible under the specific growing conditions outlined in this work.

Pine wood chips are engineered and processed to specific sizes and shapes to be functional as aggregates in a container substrate. Not all wood components are designed, or capable of improving/influencing the physical and chemical behavior of a substrate the same. As a result of the large particle nature of PWC, they likely have reduced surface area compared with small particles or wood components that have been processed in different ways/methods. The influence of particle size and surface area (internal and external) on microbial decomposition, nutrient immobilization, and $\mathrm{pH}$ buffering (among other things) is not well understood for wood substrate components, but it is believed to be highly significant. For example, wood processed into fibers (increased surface area) and amended with peat may show different $\mathrm{N}$ requirements (microbial populations) and plant growth response during cultivation, in addition to changing the substrate air and water relations much differently than PWC-sized particles. On the basis of the known variability of many wood components being developed, commercialized, marketed, and sold on the market today, it is highly suggested that any and all substrate wood components should not be considered the same and be tested/trialed before large-scale use.

\section{Literature cited}

Argo, W.R. and P.R. Fisher. 2002. Understanding $\mathrm{pH}$ management for container-grown crops. Meister Publ., Willoughby, $\mathrm{OH}$.

Boyer, C.R., G.B. Fain, C.H. Gilliam, T.V. Gallagher, H.A. Torbert, and J.L. Sibley. 2008. Clean chip residual: A substrate component for growing annuals. Hort Technology 18:423-432.

Boyer, C.R., H.A. Torbert, C.H. Gilliam, G.B. Fain, T.V. Gallagher, and J.L. Sibley. 2012. Nitrogen immobilization in plant growth substrates: Clean chip residual, pine bark, and peatmoss. Intl. J. Agr. 2012:978528.

Cavins, T.J., B.E. Whipker, W.C. Fonteno, B. Harden, I. McCall, and J.L. Gibson. 2000. Monitoring and managing $\mathrm{pH}$ and EC using the pour thru extraction method. North Carolina State Univ. Hort. Info. Lflt. 590.

Fain, G.B., C.H. Gilliam, A.L. Witcher, J.L. Sibley, and C.R. Boyer. 2008. WholeTree substrate and fertilizer rate in production of greenhouse-grown petunia (Petunia $\times$ bybrida Vilm.) and marigold (Tagetes patula L.). HortScience 43:700-705.

Gerber, T., F. Steinbacher, and B. Hauser. 1999. Wood fiber substrate for cultivating Pelargonium hortum L.-Biophysical examinations and plant growth. J. Appl. Bot. 73:217-221.
Handreck, K.A. 1991. Nitrogen drawdown key to optimum growth. Austral. Hort. 12:38-43.

Handreck, K.A. 1993. Use of the nitrogen drawdown index to predict fertilizer nitrogen requirements in soilless potting media. Commun. Soil Sci. Plant Anal. 24:2137-2151.

Hicklenton, P.R. 1983. Flowering, vegetative growth and mineral nutrition of pot chrysanthemums in sawdust and peat-lite media. Sci. Hort. 21:189-197.

Jackson, B.E. and R.D. Wright. 2009. Pine tree substrate: An alternative and renewable growing media for horticulture crop production. Acta Hort. 819:265-272.

Jackson, B.E., R.D. Wright, and M.M. Alley. 2009a. Comparison of fertilizer nitrogen availability, nitrogen immobilization, substrate carbon dioxide efflux, and nutrient leaching in peat-lite, pine bark, and pine tree substrates. HortScience 44:781-790.

Jackson, B.E., R.D. Wright, and M.C. Barnes. 2008a. Pine tree substrate, nitrogen rate, particle size, and peat amendment affects poinsettia growth and substrate physical properties. HortScience 43:2155-2161.

Jackson, B.E., R.D. Wright, J.F. Browder, J.R. Harris, and A.X. Niemeria. 2008b. Effect of fertilizer rate on growth of azalea and holly in pine bark and pine tree substrates. HortScience 43:1561-1568.

Jackson, B.E., R.D. Wright, and N. Gruda. 2009b. Container medium $\mathrm{pH}$ in a pine tree substrate amended with peatmoss and dolomitic limestone affects plant growth. HortScience 44:1983-1987.

James, E.C. and M.W. van Iresel. 2001. Fertilizer concentration affects growth and flowering of subirrigated petunias and begonias. HortScience 36:40-44.

Kang, J.G. and M.W. van Iresel. 2001. Interactions between temperature and fertilizer concentration affect growth of subirrigated petunias. J. Plant Nutr. 24:753-765.

Kang, J.G. and M.W. van Iresel. 2009. Managing fertilization of bedding plants: 
A comparison of constant fertilizer concentrations versus constant leachate electrical conductivity. HortScience 44:151-156.

McKenzie, W.M. 1958. The effect of nitrogen availability of adding fragmented wood to soil. Austral. J. Agr. Res. 9:664-679.

Nau, J. 2011. Ball redbook: Crop production. 18th ed. Vol. 2. Ball Publ., West Chicago, IL.

Nelson, P.V. 2012. Greenhouse operation and management. 7th ed. Prentice Hall, Upper Saddle River, NJ.
Nemali, K.S. and M.W. van Iersel. 2004. Light intensity and fertilizer concentration: I. Estimating optimal fertilizer concentrations from water-use efficiency of wax begonia. HortScience 39:1287-1292.

Whipker, B.E., J.M. Dole, I.J. Cavin, J.L. Gibson, W.C. Fonteno, P.V. Nelson, D.S Pitchey, and D.A. Bailey. 2001. Plant root zone management. North Carolina Flower Growers’ Assn., Raleigh, NC.
Wright, R.D. 1986. The pour-through nutrient extraction procedure. HortScience 21:227-229.

Wright, R.D. and J.F. Browder. 2005. Chipped pine logs: A potential substrate for greenhouse and nursery crops. HortScience 40:1513-1515.

Wright, R.D., B.E. Jackson, J.F. Browder, and J.G. Latimer. 2008. Growth of chrysanthemum in a pine tree substrate requires additional fertilizer. HortTechnology 18: 111-115. 